\title{
PV integrated series active filter for sag voltage and harmonic compensation
}

\author{
Abdelmalek Meftouhi' ${ }^{1}$, Othmane Abdelkhalek ${ }^{2}$, Ahmed Allali ${ }^{3}$ Abdallah Ben Abdelkader ${ }^{4}$ \\ Toufik Toumi ${ }^{5}$ \\ 1,3,4,5 Faculty of Electrical Engineering, University of Sciences and Technology of Oran Med Boudiaf, Algeria \\ ${ }^{2}$ Faculty of Technology, University of Tahri Mohammed Bechar, Algeria
}

\begin{tabular}{l}
\hline \hline Article Info \\
\hline Article history: \\
Received Dec 27, 2018 \\
Revised Feb 7, 2019 \\
Accepted Mar 12, 2019 \\
\hline
\end{tabular}

\section{Keywords:}

Boost converter Fuzzy logic controller Harmonic voltage Photo voltaic system PI controller Series active filter

\begin{abstract}
The use of loads in the past few days is becoming vast, giving an alarm signal to the power system and electronics engineers in terms of power quality. Due to the large amount of non-linear power electronics, utilities frequently experience voltage and harmonic distortions every day. In this paper, the combination of the Series active power filter SAPF with a PV source is deliberated. The PV based on the SAPF aims to compensate voltage deviations or disturbances that occur in the system caused by power quality issues. The proposed system consists of a PV source connected to the DC link through two dc-dc converters, the first extracts the maximum power of the PV source through pulse with modulation PWM signals generated from the maximum power point tracker MPPT controller. Thus, the second converter is used to regulate the high voltage side of the converter through closed control loops using Fuzzy Logic Controller FLC, in addition to a voltage source inverter VSI and a series injection transformer. Despite of fluctuations of the DC link during the compensation of the needed energy, MPPT and closed control loops generate PWM signals to the switching devices of dc-dc boost converters in order to extract maximum PV power and to maintain the bus voltage within its limits and around its reference values respectively. The proposed topology is simulated in Matlab Simulink software, where simulation results show that the proposed PV based SAPF can efficiently reduce problems of voltage sag and harmonic.
\end{abstract}

Copyright (C) 2019 Institute of Advanced Engineering and Science. All rights reserved.

\section{Corresponding Author:}

Abdelmalek Meftouhi,

Département de Génie Electrique, Faculté de l'électrotechnique,

Université des Sciences et la Technologie d'Oran Mohamed Boudiaf (USTO-MB),

BP 1505, El M'naouer, 31000, Oran, Algeria

Email: abdelmalek_08230@yahoo.fr

\section{INTRODUCTION}

Power supply and energy quality have been critical issues in power systems recently. The photovoltaic generator (PV) connected to the grid is becoming increasingly popular because of its reliable performance and its ability to generate energy from clean energy resources [1]. The continuous output voltage of the photovoltaic panels is connected to a DC / DC boost converter using a maximum power point tracking controller (MPPT) to maximize the energy produced [2]. The development of a means to compensate for disturbances in the distribution system is also urgent. In this case, the photovoltaic generators must provide the utility with a distorted compensation capacity, which makes the currents injected / absorbed by the utility to be sinusoidal [3]. Therefore, the compensation function can be performed by an fexible control of dc/ac VSC.The proliferation of electronic equipment pollutes electricity distribution networks with harmonics, distorting waveforms of voltage and current. At the same time, the user monitors the impact of excessive warming and 
accelerated aging on the electrical installations of the electrical equipment. This phenomenon has another influence on the operation of the application; In addition, it has a direct influence on the supply of sensitive loads. Finally, this has an impact on the electrical power available in the installation because there is overconsumption due to harmonics [4,5]. The serial active filter (SAPF) is used and implanted between the delivery point (PCC) and the load to be protected. So we can say that the active filter series (SAPF) is a solution adapted to the compensation of disturbing voltages, harmonics [6]. In this study, an SAPF was adopted and modeled to improve power quality influenced by disturbances. The proposed system is powered by the PV containing a combination of two serial boosts, sharing a common DC voltage generated by the PV. The document is organized as follows: The configuration of SAPF powered by the PV will be presented in section 2. It also highlights the required units such as power source, linear load, SAPF and control engineering algorithms. Then, the main results of the simulation, current and voltage waveforms and THD analyzes will be discussed in section 3. Finally, the document will be completed by the concluding remarks.

\section{DESCRIPTION SYSTEM}

\subsection{Principle of operation}

The serial active filter is coupled in series with the load. It is regulated in order to reach the disturbed and essential harmonic voltages of the load [7-10]. Therefore, the utility wants to provide only the active part of the fundamental element of the charging current, which avoids the problems of energy pollution along the power line. In this proposed system, solar energy is integrated into the SAPF system to maintain its capacitor voltage. This type of configuration works both in interconnected mode and in isolated mode. Figure 1 shows the general block diagram of the integrated PV SAPF system. The main purpose of using PV in SAPF is: The capacitor voltage must be kept within its limits for stable and continuous operation of the voltage source inverter and also to eliminate the difficulty related to variable DC bus voltage.

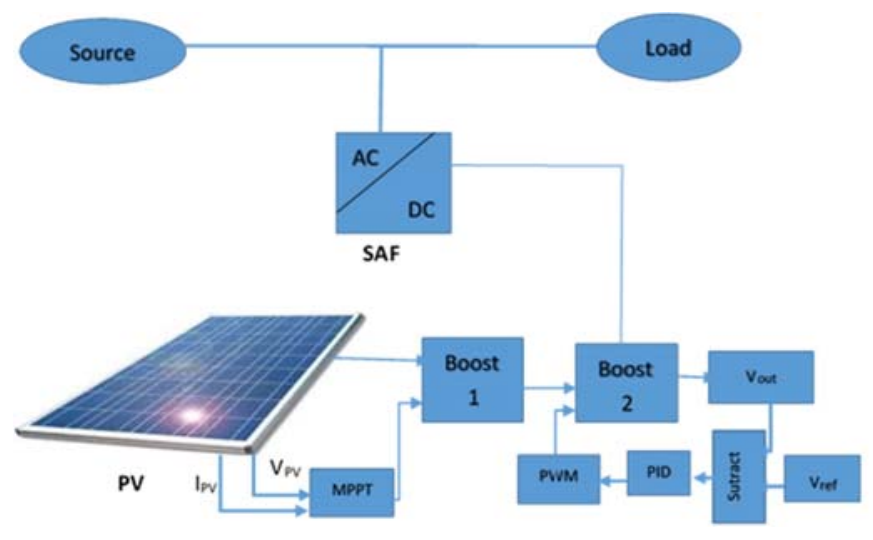

Figure 1. Overall block diagram of PV-SAPF

The proposed work presents a grid connected PV system for residential application. Figure.1 shows the typical structure of a two-stage single-phase grid-connected photovoltaic PV system.

SAPF [11-13] injects a voltage component that is connected in series with the supply voltage, thus offsetting the voltage bends and swells on the load side. The control response is of the order of $3 \mathrm{~ms}$, guaranteeing a secure voltage supply in transient conditions. The main function of an SAPF is the protection of sensitive loads against voltage drops / swells from the network. SAPF is located on the basis of sensitive loads. If a fault occurs on other lines, the SAPF inserts the serial voltage and compensates the charging voltage to the default value. The momentary amplitudes of the voltages of the three injected phases are controlled so as to eliminate any detrimental effect of a bus fault on the charging voltage.

\section{MODELLING OF PV ARRAY}

A Solar cell is the basic unit of a photovoltaic PVsystem. Combination of solar cells in series forms a PV panel or PV module. These modules when connected in series and parallel form PV arrays. Modelling of PV array has been done considering single diode of PV cell [14].

Int J Pow Elec \& Dri Syst, Vol. 10, No. 3, Sep 2019 : 1255 - 1262 


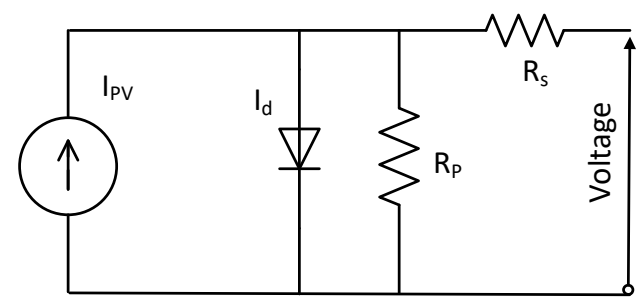

Figure 2. Single-diode model of the theoretical PV device

Figure 2: shows the equivalent circuit of the ideal photovoltaic cell. The basic equation which describes the I-V characteristics of ideal PV cell is given as [15]:

$$
\mathrm{I}=I_{P V, \text { cell }}-I_{d}
$$

That is

$$
I=I_{P V, \text { cell }}-I_{0, \text { cell }}\left[\exp \left(\frac{q V}{a K T}\right)-1\right]
$$

Where

$$
I_{d}=I_{0, \text { cell }}\left[\exp \left(\frac{q V}{a K T}\right)-1\right]
$$

Where

IPV, cell: Current generated by incident light.

Id: Shockley diode current in A,

I0, cell: Reverse saturation current of diode in A,

$q$ : electron charge $[1.602 \times 10-19 C]$,

$k$ : Boltzmann constant $[1.308 \times 10-23 \mathrm{~J} / K]$,

$\mathrm{T}[\mathrm{K}]$ : temp.of p-n junction

But practically (1) requires an inclusion of additional parameters as follows:

$$
I=I_{P V}-I_{0, \text { cell }}\left[\exp \left(\frac{V+R_{S} I}{V_{t} a}\right)-1\right]-\left(\frac{V+R_{S} I}{R_{P}}\right)
$$

Where

$\mathrm{R}_{\mathrm{s}:}$ series resistance of $P V$ device

$R_{P}$ : shunt resistance of $P V$ device

$$
V_{t} \frac{N_{S} K T}{q}
$$

Ns: Number of PV cells in series.

All PV array data sheets brings the basic information about the PV cell such as:

1) The nominal open circuit voltage $V_{0 C, n}$

2) Nominal short circuit current, $I_{s c, n}$

3) Voltage \& current at maximum power point, $V_{m p}, I_{m p}$

4) Maximum peak output voltage, $I_{\max }$

\subsection{Maximum power point tracking (MPPT)}

Many methods for maximum power point tracking MPPT were developed to allow the system to extract the maximum power from the photovoltaic generator (PV generator). The principle of this control algorithm is to generate disturbances by reducing or increasing the duty cyclic D and observe the effect on the power output of PV generator. The problem with this algorithm summarized with two points:

a. The oscillation around the maximum power point under normal operating conditions. 
b. The poor convergence of the algorithm in the case of abrupt changes in temperature and/or illumination.

\subsection{Algorithm of $P \& O$}

The P\&O is the simplest method which senses the PV array voltage and the cost of implementation is less and hence easy to implement. The time complexity of this algorithm is very less but on reaching very close to the MPP it doesn't step at the MPP and keeps on perturbing in both the directions.

As shown in Figure. 3 the $\mathrm{P} \& \mathrm{O}$ algorithm operates by periodically perturbing the operating voltage and comparing it with the previous instant. If the power difference $\Delta \mathrm{P}$ and the voltage difference $\Delta \mathrm{V}$, both in the positive direction then there is an increase in the array voltage. If either the voltage difference or the power difference is in the negative direction then there is a decrease in the array voltage. If both the voltage and power difference are in the negative direction then there is a increase in the array voltage. Similarly the next cycle is repeated until the Maximum Power Point is tracked.[16]

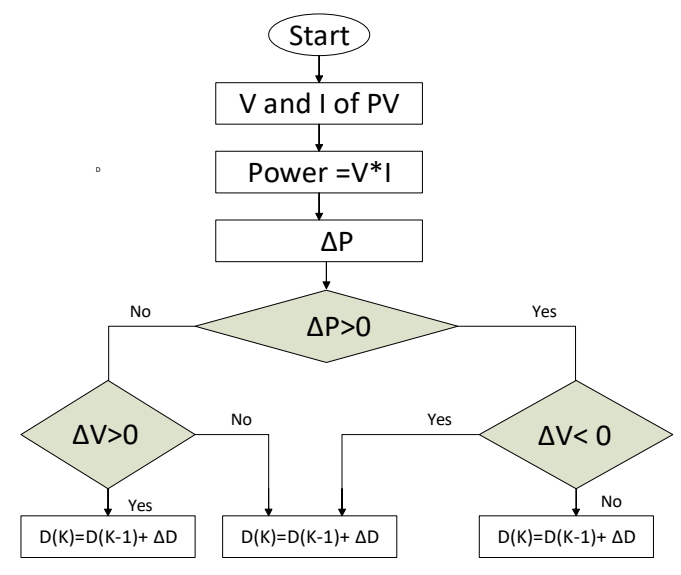

Figure 3. Algorithm P\&O

\section{SYSTEM CONTROL}

All power systems must have a control strategy that describes the interactions between its parts. The controll strategie used in this work are PI, FLC controllers. This control is described as follow:

\subsection{Fuzzy logic controller FLC}

The controller used in this paper is the FLC in order to improve the behavior of the SAPF. The structure of a fuzzy control, shown in the Figure 4, can be broken down into three major modules.

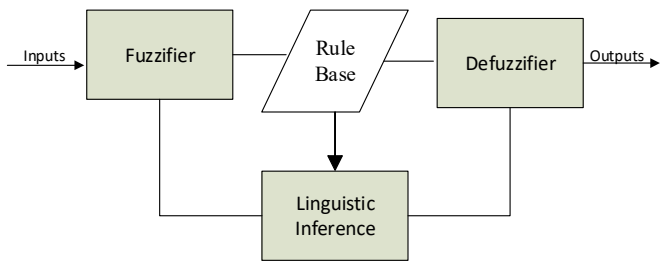

Figure 4. Fuzzy controller

The first of these modules deals with the inputs of the system: it is the fuzzification. It allows to associate to each of the actual inputs, by means of membership functions, a degree of belonging for each of the fuzzy subsets defined over the entire speech.

The second module consists of the inference engine and the rule base. This consists of the rules of the type: "If Then" and will make it possible to go from the degrees belonging to the input quantities to the degrees belonging to the fuzzy subsets of the magnitude control. The inference engine will allow you to generate a

Int J Pow Elec \& Dri Syst, Vol. 10, No. 3, Sep 2019 : 1255 - 1262 
conclusion from the inputs and active rules. It then calculates the degrees of membership of the fuzzy subsets corresponding to the control of the system.

Finally, the last module, the de-Fuzzification interface, will make it possible to transform the degrees of belonging of the fuzzy command subassemblies into numeric magnitude. This is the inverse transformation of the fuzzification module.rules in the rule base aims to compute the fuzzy output functions. Finally, by defuzzifying the fuzzy output functions, we get "crisp" output values.

These outputs are determined using the inference engine and the rule base (if-then rules) as follow: IF e AND $\triangle \mathrm{e}$, THEN Kp AND Ki. The variation of Kp and Ki constants depend on (e and $\Delta \mathrm{e}$ ). The membership function curves of e, $\Delta \mathrm{e}, \mathrm{Kp}$ and $\mathrm{Ki}$ are shown in Figure 5 and Figure 6, where all memberships' functions have triangular shape [17].

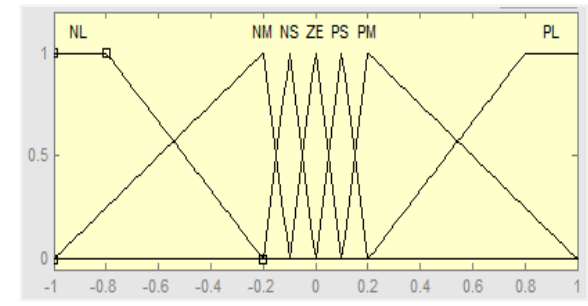

(a)

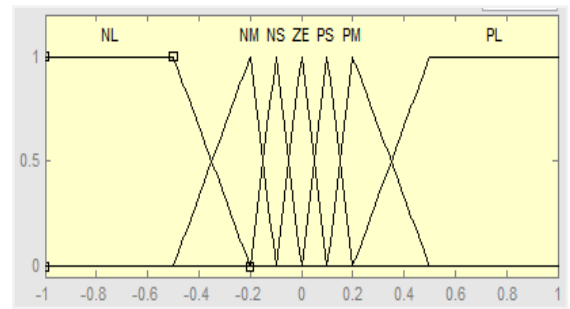

(b)

Figure 5. Membership function, (a) curves of the input e, (b) curves of the input $\Delta \mathrm{e}$

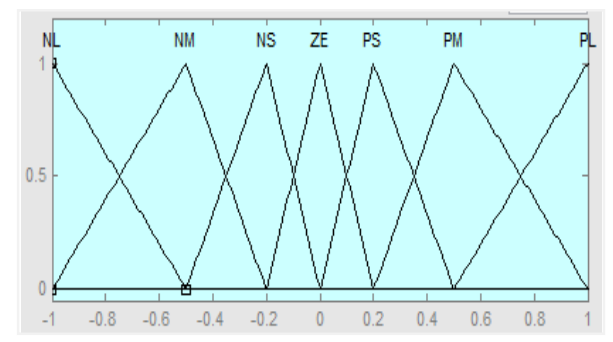

Figure 6. Membership function curves of the input $\mathrm{Kp}$ and $\mathrm{Ki}$

Thus, the fuzzy subset for e and $\Delta \mathrm{e}$ are (NL; NM, NS, ZE, PS, PM, PL). Table 1 presents the fuzzy logic control rules for the variables $\mathrm{Ki}$ and $\mathrm{Kp}$.

Table 1. Rule base for fuzzy controller

\begin{tabular}{cccccccc}
\hline $\begin{array}{c}\text { de(n) } \\
\text { e(n) }\end{array}$ & NB & NM & NS & ZE & PS & PM & PB \\
\hline NB & NB & NB & NB & NB & NM & NS & ZE \\
NM & NB & NB & NB & NM & NS & NZ & PS \\
NS & NB & NB & NM & NS & NZ & PS & PM \\
ZE & NB & NM & NS & ZE & PS & PM & PB \\
PS & NM & NS & ZE & PS & PM & PB & PB \\
PM & NS & ZE & PS & PM & PB & PB & PB \\
PB & ZE & PS & PM & PB & PB & PB & PB \\
\hline
\end{tabular}

In addition, a 3D curve of the relation between inputs and outputs of the FL controller is also plotted and shown in Figure 7. 


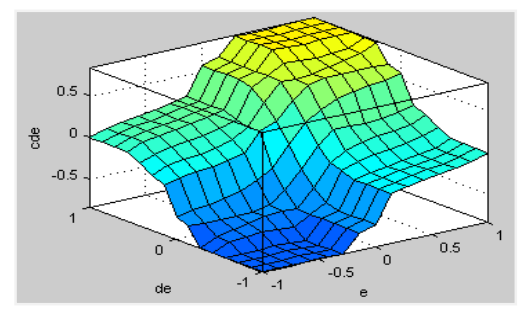

Figure 7. The relation surface between inputs and output of FLC

\section{SIMULATION RESULTSNAND DISCUSSIONS}

To confirm the effectiveness of the proposed SAPF fed by PV system controlled by Fuzzy Logic, simulations were developed in MATLAB $\backslash$ Simulink.the parameters which have been used in the simulation are shown in Table 2, in these simulation we use two DC DC (boost converter) the first one to extract the maximum power of the PV and the second used to regulated the DC voltage.the Total Harmonic Distortion (THD) of the source Voltage was found to be $33.33 \%$ befor the implementation of the SAPF-PV. Figure 9 shows the injected voltage waveforme at $1.2 \mathrm{sec}$.after the implementation of the proposed inverter, ,the THD valueis reduced to $2.94 \%$ as shows in Figures 16, Figure 17 and Figure 15 shows the output of DC voltage of the second Boost.

Table 2. Electrical parameters

\begin{tabular}{llll}
\hline Parameters & Value & Parameters & Value \\
\hline Source voltage fréquence $f$ & $50 \mathrm{~Hz}$ & Imax & $1.83 \mathrm{~A}$ \\
Source voltage Vs & $5.7 \mathrm{v} \mathrm{RMS}$ & VOC & $27.6 \mathrm{~V}$ \\
Load resistance RL & $12,3 \Omega$ & ISC & $2.06 \mathrm{~A}$ \\
CF(LC filter) & $1 \mathrm{nF}$ & Irradiation & $1000 \mathrm{~W} / \mathrm{m}^{2}$ \\
LF(LC filter) & $9 \mathrm{mH}$ & Temperature & $25^{0} \mathrm{c}$ \\
Transformer & $12 \mathrm{~V} / 230 \mathrm{~V} 1 \mathrm{kVA}$ & $\mathrm{L} 1$ & $3.2 \mathrm{mH}$ \\
dc-bus capacitor C & $22000 \mathrm{uF}$ & $\mathrm{C} 1$ & $8.62 \mathrm{e}-05 \mathrm{~F}$ \\
reference vdc voltage & $\mathrm{vdc}=75 \mathrm{v}$ & $\mathrm{L} 2$ & $1.7 \mathrm{e}-03 \mathrm{H}$ \\
Kp,Ki Simulation results & $\mathrm{Kp}=7,2-\mathrm{Ki}=33$ & $\mathrm{C} 2$ & $2200 \mathrm{e}-6 \mathrm{~F}$ \\
Vmax & $19.7 \mathrm{~V}$ & & \\
\hline
\end{tabular}

\subsection{Case of SAG voltage}

The sag phenomena was applied on the source voltage during the period between [1.2-2] second, which is corrected via the injected voltage of the SAPF as shown in Figure 8. The injected voltage of the SAPF via the injection transformer is viewed in Figure 9. Consequently, the magnitude of the load voltage was kept stable despite of the applied sag phenomena as illustraited in Figure 10. During the sag phenomina, in the DC side, the DC voltage across the input capacitance of the inverter was maintained around its nominal value of $75 \mathrm{~V}_{\mathrm{DC}}$ shown in Figure 11 through two stage DC-DC converters associated with the PV source, where the first converter aims to extract the maximum power of the PV, and the second is used to regulate the output DC voltage connected to the inverter.

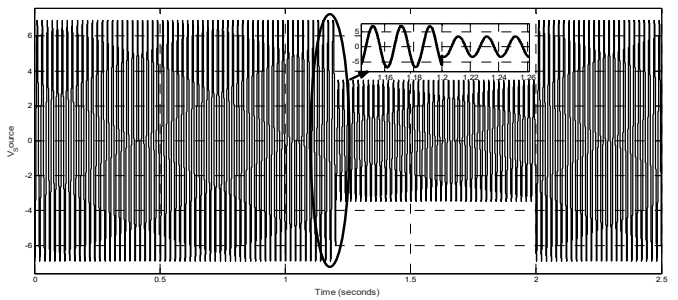

Figure 8: The source voltage (SAG)

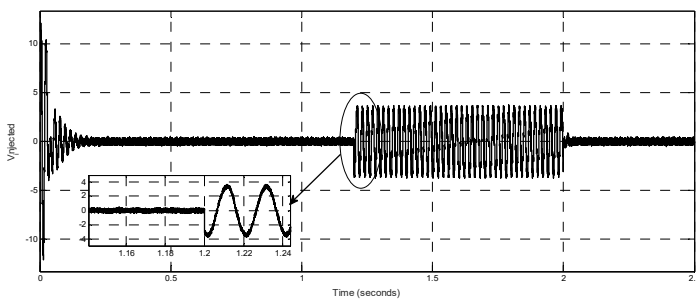

Figure 9: The voltage Injected (SAG) 


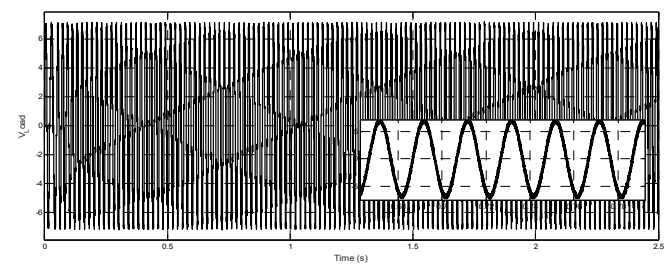

Figure 10: The Load voltage (SAG)

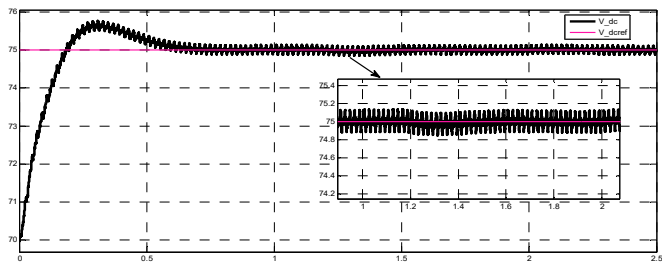

Figure 11: The DC voltage (SAG)

\subsection{Case of harmonic voltage}

In the second case, the AC programmable source was used to generate the $5^{\text {th }}$ order harmonic with the magnitude and the angle phase of $0.2 \mathrm{pu}$ and $35^{\circ}$ respectively. The applied harmonic were nearly eliminated using the SAPF by injecting the complementary voltage as seen in Figures 12 and 13. The regulated voltage at the DC side was maintained and regulated as seen in the first case of the sag phenomena as shown in Figures 14 and 15. In Figures 16 and 17, before the application of the disturbance, the total hamrmonics distortion THD was about $33.33 \%$, where after the correction it was about $2.94 \%$, which provide improved THD values and ameliorated power quality.

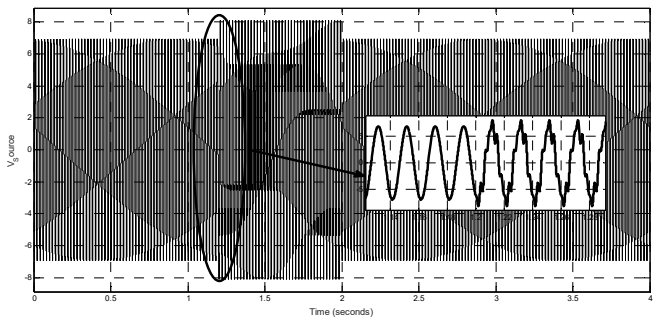

Figure 12: The source voltage (Harmonic)

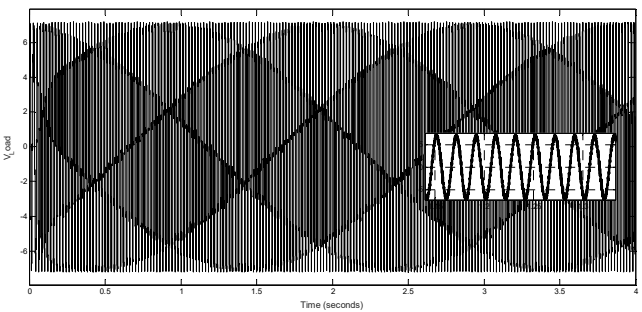

Figure 14: The Load voltage (Harmonic)

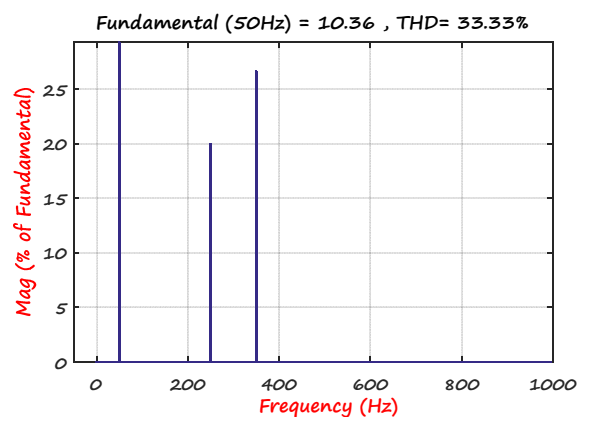

Figure 16: The FFT of source voltage befor using SAPF-PV (Harmonic)

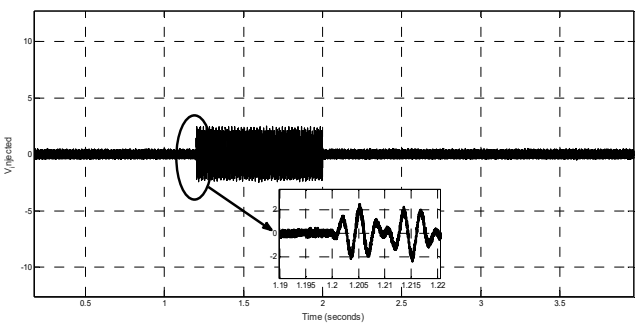

Figure 13: The injected voltage (Harmonic)

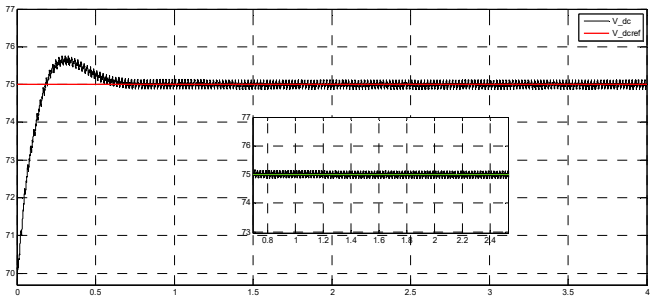

Figure 15: The DC voltage (Harmonic)

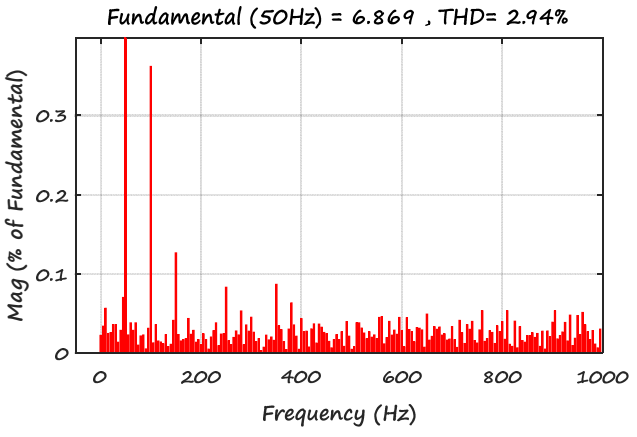

Figure 17: The FFT of source voltage after using SAPF-PV (Harmonic)

Title of manuscript is short and clear, implies research results (First Author) 


\section{CONCLUSION}

In this paper, the design and simulation of a new SAPF system wich was fed by a renewable energy source is proposed. The proposed system also incudes two conventional boost converter to compensate the reactive power ,harmonic, voltage sags at load.The PV system includes an MPPT algorithm to extract the maximum power of the panel.the second Boot was controlled by fuzzy logic controller.the simulation work carried out under Matlab simulink,from this simulation we can see that the THD of the source voltage is reduced from $33,33 \%$ to $2,94 \%$ with the SAPF-PV,the future work is an experimental results to comper with simulation works.

\section{ACKNOWLEDGEMENTS}

The authors would like to thank the Laboratory of the Smart Grids \& Renewable Energies of Béchar (SGRE), and LDDEE, Sustainable Development of Electrical Energy Algeria for funding this research project.

\section{REFERENCES}

[1] L. Hassaine, E. Olias, J. Quintero, and M. Haddadi, "Digital power factor control and reactive power regulation for grid-connected photovoltaic inverter,"' Renewable Energy, vol. 34(1), pp. 315321, 2009.

[2] I. Houssamo, F. Locment, and M. Sechilariu, "Experimental analysis of impact of MPPT methods on energy efficiency for photovoltaic power systems," Int. J. Elect. Power Energy Syst., vol. 46, pp. 98-107, Mar. 2013.

[3] M. El-Habrouk, M. K. Darwish, and P. Mehta, "Active power filters: Areview," Proc. IEE Elect. Power Appl., vol. 147(5), pp. 403-413, Sep. 2000.

[4] M. Zadehbagheri, R Ildarabadi, M.Baghaeinejad, T. Sutikno "A new structure of dynamic voltage restorer based on asymmetrical-source inverters to compensate voltage disturbances in power distribution networks," International Journal of Power Electronics and Drive System (IJPEDS), vol. 8(1), pp. 344-359, Mar 2017.

[5] A. Ramos, I. Nuez and V. Feliu, "Linearisation method and control for series active p ower filter by means of pulsewidth modulation," IEE Proc.-Electr. Power Appl., vol. 153(3), May 2006.

[6] E.R. Ribeiro, 1. Barbi, "Harmonic voltage reduction using a series active filter under different load conditions," IEEE Transactions Electronics, vol. 21(5), pp. 1394-1402, Sep. 2006.

[7] G. Ramya, V. Ganapathy, P. Suresh, "Power quality improvement using multi-level inverter based DVR and DSTATCOM using neuro-fuzzy controller," International Journal of Power Electronics and Drive System (IJPEDS), vol. 8(1), pp. 316-324, Mar 2017

[8] H. Akagi, E. Watanabe, and M. Aredes, "Hybrid and series active filters," in Instantaneous Power Theory and Applications to Power Conditioning," 1st ed., New Jersey, Wiley-IEEE Press, pp. 221-263, 2007.

[9] E. Cipriano dosSantos, C. Jacobina, J. Dias, and N. Rocha, "Single-phase to three-phase universal active power filter," IEEE Trans. Power Del., vol. 26(3), pp. 1361-1371, Jul 2011.

[10] H. Akagi, and K. Isozaki, "A hybrid active filter for a threep hase12-pulse diode rectifier used as the front end of a medium voltage motor drive," IEEE Trans. Power Electron., vol. 27(1), pp. 69-77, Jan 2012.

[11] C. Sankaran, "Power Quality," CRC Press LLC, 2002.

[12] S. Ravi, V. Mezhuyev, K. I. Annapoorani, P. Sukumar, "Design and implementation of a microcontroller based buck boost converter as a smooth starter for permanent magnet motor," Indonesian Journal of Electrical Engineering and Computer Science, vol. 1(3), pp. 566-574, Mar.2016.

[13] S. Benabid, O. Abdelkhalek, "Unified power quality conditioner supplied by fuel cell system via SEPIC converter," International Journal of Power Electronics and Drive Systems (IJPEDS), vol. 10(1), pp. 178-194, 2018.

[14] H.S. Rauschenbach, "Solar cell array design handbook. The principles and technology of photovoltaic energy conversion," New York, N.Y.: Van Nostrand Reinhold Print, 1980.

[15] M.G.Villaiva, J.R Gazoli, E Ruppert, "Modelling and circuit based simulation of photovoltaic arrays," Brazillian Journal of Power Electronics, vol 14(1), pp. 35-45, 2009.

[16] T. Chaitanya, Ch. Saibabu, J.Surya Kumari, "Modeling and simulation of PV array and its performance enhancement using MPPT (P\&O) technique," International Journal of Computer Science \& Communication Networks, vol 1(1), Sep-Oct 2011.

[17] A. Ben abdelkader O. Abdelkhalek and A. Allali., "Experimental validation of single phase series active power filter using fuzzy control technique," International Journal of Power Electronics and Drive Systems (IJPEDS), vol. 9(2), pp. 591-601, 2018.

Int J Pow Elec \& Dri Syst, Vol. 10, No. 3, Sep 2019 : 1255 - 1262 